\title{
Vermicompost Formulation Based on Soybean Husk and Cow Manure on Shallots
}

\author{
Sri Mursiani Arifah ${ }^{1,2^{*}}$, Maria Theresia Sri Budiastuti ${ }^{3}$, Widyatmani Sih Dewi ${ }^{4}$, Supriyadi ${ }^{4}$ \\ ${ }^{1}$ Department of Agriculture Science, Sebelas Maret University, Surakarta 57126, Indonesia \\ ${ }^{2}$ Department of Agrotechnology, Faculty of Agriculture University Muhammadiyah of Malang, Malang 65144, Indonesia \\ ${ }^{3}$ Department of Agrotechnology, Faculty of Agriculture, Sebelas Maret University, Surakarta 57126, Indonesia \\ ${ }^{4}$ Department of Soil Science, Faculty of Agriculture, Sebelas Maret University, Surakarta 57126, Indonesia
}

Corresponding Author Email: srimursiani64@gmail.com

https://doi.org/10.18280/ijdne.160312

Received: 3 May 2021

Accepted: 15 June 2021

\section{Keywords:}

organic matter, fertilizer, growth, yield,

Randomized Complete Block Design (RCBD)

\begin{abstract}
Shallot is one of an important vegetable in Indonesia. The yield of the crop is often constrained by low and unbalanced nutrient supply in the soil. The application of vermicompost based on soybean husk and cow manure can increased nutrient supply in the soil. This research aimed to obtain the optimum vermicompost formulation and doses based on soybean husk and cow manure on shallots. This research is a field that arranged Randomized Complete Block Design (RCBD) with 1 factor (vermicompost formulation (V) that consisted 4 doses for each treatment and 3 replication was applied. The treatment consisted of vermicompost formulation (V): 100\% soybean husk, $100 \%$ cow manure, 50\% soybean husk: $50 \%$ : cow manure, $75 \%$ soybean husk: $25 \%$ : cow manure and $25 \%$ soybean husk: $75 \%$ : cow manure. Each treatment consisted of four doses: without application, 5, 10, $15 \mathrm{t}^{\text {. ha }}{ }^{-1}$, so the total treatment was 20 level. Data were analyzed using the least significant difference (LSD) test. The result indicated that vermicompost formulation gave significant effect on all of observation parameters on the growth and yield. The lowest response of shallots occurred in the treatments without vermicompost application on all formulations, and the highest was in the $100 \%$ soybean husk formulation at a dose of $15 \mathrm{t} \mathrm{ha}^{-1}$.
\end{abstract}

\section{INTRODUCTION}

Shallot is a vegetable that is used as a spice, widely cultivated in Southeast Asia [1]. The problem of shallots is largely due to low production. This is related to the decreasing quality of land due to the continuous use of inorganic fertilizers, due to increased acidity and environmental pollution, pest resistance development and food safety decline [2-4]. Therefore, there needs to be technical action to improve land conditions with the use of organic fertilizers. The availability of sufficient organic fertilizers in the soil will provide energy for microorganism to carry out their activities, especially in the process of decomposition and mineralization of organic fertilizers, so that the biological conditions of the soil can be improved [5, 6]. This condition will further increase nutrient content, increase water retention, improve soil structure and texture so that it can stabilize soil aggregates $[7,8]$.

Vermicompost was a solid product from vermicomposting, it could be used as an organic fertilizer. The quality of vermicompost was better compared to other organic fertilizers, because it was the result of the degradation of organic waste which involved interactions between earthworms and microorganisms [9-11]. The earthworms had enzymes such as protease, lipase, amylase, cellulose and chitin which would provide rapid chemical changes to the cellulose material and protein from waste [12-14]. Vermicompost had a high enough nutrient content such as nitrate, phosphate, and calcium which could be exchanged and potassium which could be exchanged soluble in forms available for plants [15-19], growth substances such as humic acid, fulvic acid, other organic acids, auxins and cytokines [20, 21]. Some active bacteria like Azotobacter sp., Arobactericum sp. and Rhizobium sp. [22-25], environmentally friendly because it could revitalize soil quality [26], become biocontrol for plants, where vermicompost contains organisms that could control plant pathogens [27]. The advantage of vermicompost had been proven in several types of onions [28], tomatoes [29, 30], strawberries [31], capsicum [32] which were given vermicompost, where all the results of the study showed better significance for plant growth and yield.

As stated above, the quality of organic fertilizer including vermicompost was determined by the raw material used. In this study, vermicompost used as raw material from soybean husk and cow manure. Soybean husk was organic waste obtained from the process of stripping soybeans on several processed products such as oil, flour, milk, soy sauce, tofu and tempeh. So far, soybean husk was only used as animal feed, while on the other hand that basically all organic material could be used as organic fertilizer, then this waste had the potential to be used as organic fertilizer. This had been proven by ref. [33] from the results of the study conducted by combining soybean husk with papaya, showed a significant increase in the content of $\mathrm{P}, \mathrm{K}, \mathrm{Ca}$ and $\mathrm{Mg}$ and a decrease in $\mathrm{C} / \mathrm{N}$ ratio. This indicated that soybean husk was indeed very potential to be used as organic fertilizer. On the other hand, the use of soybean husk as raw material in vermicomposting had not been done much especially in combination with livestock 
manure.

The choice of cow manure as raw material in combination with soybean husk was done because cow manure was a type of manure which in addition to the high diversity of microorganisms also had the highest fiber content such as cellulose compared to other livestock manure. This was indicated by the high $\mathrm{C} / \mathrm{N}$ ratio that was more than 30 . This condition was actually needed by earthworms as additional energy so that cow manure was a good substrate if used as a mixture of media on vermicomposting [34, 35]. Therefore, in this study, the combination of soybean husk and cow manure in different proportions was tested to determine the potential of soybean husk as organic fertilizer on shallots with several dosage applications.

The purpose of this study was to obtain the optimum dose of vermicompost formulation made from soybean husk and cow manure on shallots, so that it could be used as a reference in the application of local wisdom-based organic fertilizer. Furthermore, long-term use of inorganic fertilizers could be replaced with organic fertilizers. This condition aimed to lead to food security and the environment and to ensure a sustainable and environmentally friendly agricultural production process.

\section{MATERIAL AND METHOD}

The experiment was conducted in the experimental garden of University Muhammadiyah of Malang, East Java, Indonesia (550 $\mathrm{m}$ above sea level) (Figure 1). The materials were used include Blue Lancor variety shallots, vermicompost, NPK fertilizer and pesticides. Randomized Complete Block Design (RCBD) with one factor and three replications. The treatment consisted of vermicompost dose (V): $100 \%$ soybean husk, $100 \%$ cow manure, 50\% soybean husk: 50\%: cow manure, $75 \%$ soybean husk: $25 \%$ : cow manure and $25 \%$ soybean husk: $75 \%$ : cow manure. Each treatment consisted of four doses: without application of vermicompost, 5 t.ha ${ }^{-1}, 10$ t.ha $^{-1}$ and 15 t. ha ${ }^{-1}$ so the total treatment was 20 level.

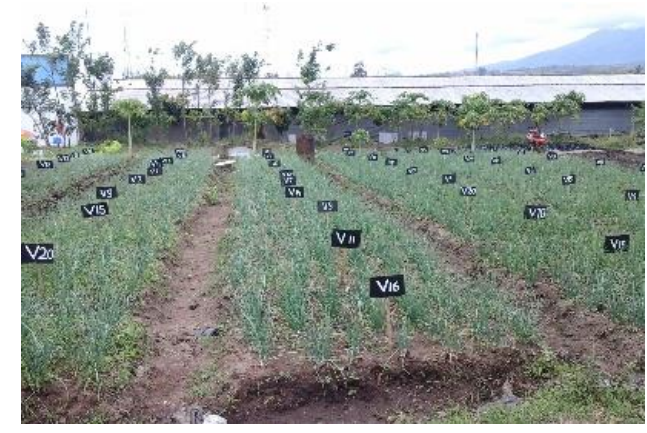

Figure 1. Shallot plantation at the experimental garden (30 days after planting/dap)

Plant preservation included watering and controlling pests, diseases and weeds. Watering was conducted in the morning or evening, especially in the early to mid-plant growth, this was due to coincide with the rainy season, so it was not conducted. Pest was controlled by spraying pesticides, selection of pesticides based on the habits of farmers in the research area, the active ingredient Profenofos $500 \mathrm{~g} / 1$, at a dose of 0.5 to $1 \mathrm{ml} /$ liter of water), whereas spraying of fungicides (the active ingredient Azoksistrobin dan Difenokonazol, 0.5-1 ml/liter) was carried out every time after rain. Weed control was conducted by spraying pre-growing herbicides (the active ingredient Fenoksaporp-p-etil, $20 \mathrm{ml} / 15$ liter). In the study conducted, harvesting was at 60 days after planting.

Growth variable were measured from 10 days after planting (dap) to 50 dap with intervals of 10 days. It was consisted of plant height $(\mathrm{cm})$, number of leaves, and number of tillers. While the observed yield variables included the number of bulbs per plant, bulb weight per plant (g), weight of each bulb $(\mathrm{g})$, and yield $\left(\mathrm{t} \mathrm{ha}^{-1}\right)$. Furthermore, the data obtained were analyzed by ANOVA test with the statistical model as follows:

$$
Y i j=\mu+\alpha . j+\tau i .+\delta i j
$$

$\mathrm{i}=\mathrm{V}_{1}, \mathrm{~V}_{2}, \ldots \mathrm{V}_{20}$ as a treatment $(\mathrm{t})$;

$\mathrm{j}=\mathrm{I}$, II, III as replication (r).

Explanation:

$Y i j$ : Observation data from treatment to I and replication to $\mathrm{j}$; $\mu$ : General average influence data;

$\alpha . j$ : Group influence data to $\mathrm{j}$;

$\tau i .:$ Data on the effect of treatment to I;

$\delta i j$ : Data on the effect of experimental error due to treatment to $\mathrm{i}$ and replication to $\mathrm{j}$.

The data was then processed using Least Significant Difference (LSD), which served to compare between treatments, with equation [36]:

$$
L S D=q A, \alpha \frac{\sqrt{M S s(A)}}{S}
$$

$q A, \alpha=\mathrm{q}$ table $(\alpha 5 \%)$.

$\operatorname{MSs}(A)=$ mean square of error.

$S=$ replication.

\section{RESULTS AND DISCUSSIONS}

\subsection{Effect vermicompost formulation based on soybean husk and cow manure on Shallot's growth}

Based on the analysis of variance (ANOVA), the formulation of vermicompost doses gave significantly effect on growth from the age of 20 days after planting (Tables 1, 2, 3 ). For the variable number of tillers, the measurements were started at the age of 20 days after planting because at the age of 10 days after planting no chicks had been formed.

Based on Table 1, the plant height increase significantly at $\mathrm{V}_{4}\left(100 \%\right.$ soybean husk) at a dose of $15 \mathrm{t} \mathrm{ha}^{-1}$, while the lowest was at treatment without application of vermicompost on all formulations at all measurement ages. Plant height at 20 days after planting was $37.73 \mathrm{~cm}, 42.37 \mathrm{~cm}$ at 30 days after planting, $52.63 \mathrm{~cm}$ at 40 days after planting and $55.73 \mathrm{~cm}$ at 50 days after planting. This plant height was $9.16 \%$ higher than the control and $6.7 \%$ higher when compared to the $100 \%$ cow manure formulation at a dose of $15 \mathrm{t}_{\mathrm{ha}} \mathrm{h}^{-1}$.

The number of leaves showed increase slowly at treatment without application of vermicompost, while the greatest number of leaves was shown at $\mathrm{V}_{4}(100 \%$ soybean husk at a dose of 15 t.ha $^{-1}$ in all measurement ages, namely 29 leaves at 20 days after planting, 39.33 age 30 days after planting, 76.67 age 40 days after planting and 72.67 age 50 days after planting. The increase in the number of leaves was $24.63 \%$ higher than the control and $18.46 \%$ higher than the $100 \%$ cow manure 
formulation at a dose of 15 t.ha-1.

Same as with plant height and number of leaves, the number of tillers also showed the same trend, which experienced the highest number of tillers in treatment $\mathrm{V}_{4}(100 \%$ soybean husk) at a dose of $15 \mathrm{t}^{\mathrm{h}} \mathrm{h}^{1}$ and relatively less number of tillers at without application of vermicompost. The number of tillers at the age of 20 was $6.33,11.33$ at the age of 30 , and reached 15.67 at the age of 40 and 50 dap. Treatment V4 with a dose of $15 \mathrm{t} / \mathrm{ha}$ showed $21.44 \%$ more tillers than control and $15.37 \%$ more than $100 \%$ cow manure formulation at a dose of 15 t.ha- ${ }^{-1}$.

Vermicompost is made from soybean husk and cow manure with several doses that have been tried to respond to the growth of shallots. At the beginning of growth (10 dap), the applied vermicompost had no significant effect on all growth parameters. This condition is due to the slow release of vermicompost so that the availability of nutrient for plants lasts a long time [37]. The availability of nutrients in the soil is related to the vermicompost overhaul process that occurs. Nutrient content in raw materials affect the speed of the process of composting [38]. Vermicompost has a surface that is wide enough for beneficial microbial activity and produces humus which functions to increase soil aggregation so that it can improve the availability of nutrients for plants as well as increase soil fertility [39] and will further improve plant health and growth [40]. Low growth occurred in the treatment without giving vermicompost on all growth parameters at all ages of observation. This condition is due to a lack of nutrient supply for plants because plants need nutrients from the beginning of growth to entering the generative phase, especially when shallots begin to enter the bulb formation phase [41].

Table 1. The effect of vermicompost formulation on plant height variable at several age measurements (days after planting/dap)

\begin{tabular}{|c|c|c|c|c|}
\hline \multirow{2}{*}{$\mathbf{T}$} & \multicolumn{4}{|c|}{ Plant Height $(\mathrm{cm})$ / age (dap) } \\
\hline & 20 & 30 & 40 & 50 \\
\hline \multicolumn{5}{|c|}{$100 \%$ soybean husk (doses t.h $\left.{ }^{1}\right)$} \\
\hline $\mathrm{V}_{1}(0)$ & $30.17 \mathrm{a}$ & $35.95 \mathrm{ab}$ & $46.10 \mathrm{ab}$ & $45.13 \mathrm{a}$ \\
\hline$V_{2}(5)$ & $33.50 \mathrm{ab}$ & 39.83 & $48.43 \mathrm{ab}$ & $.13 \mathrm{ab}$ \\
\hline $\mathrm{V}_{3}(10)$ & $36.93 \mathrm{ab}$ & & & $2.53 \mathrm{ab}$ \\
\hline & $37.73 \mathrm{~b}$ & 42.3 & & $55.73 \mathrm{~b}$ \\
\hline \multicolumn{5}{|c|}{$100 \%$ cow manure $\left(\right.$ doses .h $\left.{ }^{1}\right)$} \\
\hline $\mathrm{V}_{5}(0)$ & $29.83 \mathrm{a}$ & $33.17 \mathrm{a}$ & $41.80 \mathrm{a}$ & $17 \mathrm{a}$ \\
\hline $\mathrm{V}_{6}(5)$ & $7 \mathrm{ab}$ & & & $46.00 \mathrm{a}$ \\
\hline $\mathrm{V}_{7}(10)$ & $32.27 \mathrm{ab}$ & & & $47.63 \mathrm{ab}$ \\
\hline $\mathrm{V}_{8}(15)$ & $33.00 \mathrm{ab}$ & $37.17 \mathrm{ab}$ & $46.67 \mathrm{ab}$ & $47.97 \mathrm{ab}$ \\
\hline \multicolumn{5}{|c|}{$50 \%$ soybean husk: $50 \%$ cow manure (doses t.h $\left.{ }^{1}\right)$} \\
\hline $\mathrm{V}_{9}(0)$ & $31.33 \mathrm{ab}$ & $38.70 \mathrm{ab}$ & $46.00 \mathrm{ab}$ & $49.70 \mathrm{ab}$ \\
\hline$V_{10}(5)$ & 36 & 39.3 & 48.0 & $50.53 \mathrm{ab}$ \\
\hline & 31 & 38. & 47 & $48.97 \mathrm{ab}$ \\
\hline & $33.63 \mathrm{ab}$ & $41.97 \mathrm{~b}$ & & $51.43 \mathrm{ab}$ \\
\hline \multicolumn{5}{|c|}{$75 \%$ soybean husk: $25 \%$ cow manure (doses t.h $\left.{ }^{1}\right)$} \\
\hline $\mathrm{V}_{13}(0)$ & $30.23 \mathrm{a}$ & $33.87 \mathrm{a}$ & $42.97 \mathrm{a}$ & $43.50 \mathrm{a}$ \\
\hline$V_{14}(5)$ & $a b$ & 36. & $44.63 \mathrm{ab}$ & $49.50 \mathrm{ab}$ \\
\hline $\mathrm{V}_{15}(10)$ & $34.23 \mathrm{ab}$ & $37.73 \mathrm{ab}$ & $46.33 \mathrm{ab}$ & $49.93 \mathrm{ab}$ \\
\hline$V_{16}(15)$ & $30.83 \mathrm{ab}$ & $40.30 \mathrm{ab}$ & $51.33 \mathrm{~b}$ & $48.77 \mathrm{ab}$ \\
\hline \multicolumn{5}{|c|}{$25 \%$ soybean husk: $75 \%$ cow manure (doses t.h $\left.{ }^{1}\right)$} \\
\hline $\mathrm{V}_{17}(0)$ & $31.27 \mathrm{ab}$ & $33.53 \mathrm{a}$ & $41.50 \mathrm{a}$ & $46.40 \mathrm{a}$ \\
\hline$V_{18}(5)$ & & & $45.90 \mathrm{ab}$ & $46.53 \mathrm{ab}$ \\
\hline $\mathrm{V}_{19}(10)$ & $35.23 \mathrm{ab}$ & $39.67 \mathrm{ab}$ & $45.27 \mathrm{ab}$ & $49.50 \mathrm{ab}$ \\
\hline $\mathrm{V}_{20}(15)$ & $35.77 \mathrm{ab}$ & $38.03 \mathrm{ab}$ & $47.53 \mathrm{ab}$ & $51.10 \mathrm{ab}$ \\
\hline LSD & 7.322 & 7.968 & 9.014 & 9.188 \\
\hline
\end{tabular}

Notes: The same letters in the same column were not significant difference at $5 \%$ LSD test.
The vegetative growth of shallots measured in this study included plant height, number of leaves, and number of tillers. The application of vermicompost with different formulations and doses showed a different increase in vegetative growth in shallots. Treatment of $100 \%$ soybean husk at a dose of 15 t.ha ${ }^{1}$ showed an increase in plant height, the number of leaves, and the number of tillers was the highest compared to other treatments. Soybean husk which is a waste of beans, basically contains high enough nitrogen, so that it can be used in the metabolic processes needed for plant growth, given that nitrogen is a constituent element of amino acids which is a protein-forming compound and plays a role in all tissues. plants, encouraging cell division and high meristematic activity, also allow plants to have good proliferation and also inhibition of vermicompost nitrification processes in the soil [42].

Table 2. The effect of vermicompost formulation on number of leaves variable at several age measurements (days after planting/dap)

\begin{tabular}{|c|c|c|c|c|}
\hline \multirow{2}{*}{ Treatment } & \multicolumn{4}{|c|}{ Number of leaves / age (dap) } \\
\hline & 20 & 30 & 40 & 50 \\
\hline \multicolumn{5}{|c|}{$100 \%$ soybean husk (doses t.h ${ }^{1}$ ) } \\
\hline $\mathrm{V}_{1}(0)$ & $22.33 \mathrm{ab}$ & $24.33 \mathrm{a}$ & $51.67 \mathrm{a}$ & $29.33 \mathrm{ab}$ \\
\hline $\mathrm{V}_{2}(5)$ & $25.00 \mathrm{ab}$ & $30.33 \mathrm{abc}$ & $57.00 \mathrm{ab}$ & $53.67 \mathrm{abc}$ \\
\hline $\mathrm{V}_{3}(10)$ & $25.33 \mathrm{ab}$ & $31.67 \mathrm{abc}$ & $70.67 \mathrm{ab}$ & $68.33 \mathrm{c}$ \\
\hline $\mathrm{V}_{4}(15)$ & $29.00 \mathrm{~b}$ & $39.33 \mathrm{c}$ & $76.67 \mathrm{~b}$ & $72.67 \mathrm{c}$ \\
\hline \multicolumn{5}{|c|}{$100 \%$ cow manure (doses t.h $\left.{ }^{1}\right)$} \\
\hline $\mathrm{V}_{5}(0)$ & $14.33 \mathrm{a}$ & $23.33 \mathrm{a}$ & $49.33 \mathrm{a}$ & $26.67 \mathrm{a}$ \\
\hline $\mathrm{V}_{6}(5)$ & $15.00 \mathrm{a}$ & $26.33 \mathrm{a}$ & $55.67 \mathrm{ab}$ & $47.33 \mathrm{abc}$ \\
\hline $\mathrm{V}_{7}(10)$ & $18.33 \mathrm{ab}$ & $24.33 \mathrm{a}$ & $59.33 \mathrm{ab}$ & $50.00 \mathrm{abc}$ \\
\hline $\mathrm{V}_{8}(15)$ & $19.00 \mathrm{ab}$ & $28.67 \mathrm{abc}$ & $61.67 \mathrm{ab}$ & $52.33 \mathrm{abc}$ \\
\hline \multicolumn{5}{|c|}{ 50\% soybean husk: $50 \%$ cow manure (doses t.h $\left.{ }^{1}\right)$} \\
\hline $\mathrm{V}_{9}(0)$ & $16.33 \mathrm{a}$ & $23.67 \mathrm{a}$ & $52.67 \mathrm{a}$ & $53.00 \mathrm{abc}$ \\
\hline$V_{10}(5)$ & $23.00 \mathrm{ab}$ & $28.00 \mathrm{abc}$ & $64.33 \mathrm{ab}$ & $57.67 \mathrm{abc}$ \\
\hline $\mathrm{V}_{11}(10)$ & $23.00 \mathrm{ab}$ & $34.67 \mathrm{abc}$ & $65.00 \mathrm{ab}$ & $65.33 \mathrm{c}$ \\
\hline $\mathrm{V}_{12}(15)$ & $23.67 \mathrm{ab}$ & $38.33 \mathrm{c}$ & $68.67 \mathrm{ab}$ & $67.33 \mathrm{c}$ \\
\hline \multicolumn{5}{|c|}{$75 \%$ soybean husk: $25 \%$ cow manure (doses t.h ${ }^{1}$ ) } \\
\hline $\mathrm{V}_{13}(0)$ & $15.67 \mathrm{a}$ & $23.33 \mathrm{a}$ & $55.33 \mathrm{ab}$ & $49.33 \mathrm{abc}$ \\
\hline$V_{14}(5)$ & $16.67 \mathrm{ab}$ & $24.00 \mathrm{a}$ & $65.00 \mathrm{ab}$ & $61.00 \mathrm{bc}$ \\
\hline $\mathrm{V}_{15}(10)$ & $18.33 \mathrm{ab}$ & $27.00 \mathrm{abc}$ & $67.67 \mathrm{ab}$ & $59.00 \mathrm{bc}$ \\
\hline $\mathrm{V}_{16}(15)$ & $19.67 \mathrm{ab}$ & $34.00 \mathrm{abc}$ & $70.00 \mathrm{ab}$ & $62.67 \mathrm{c}$ \\
\hline \multicolumn{5}{|c|}{$25 \%$ soybean husk: $75 \%$ cow manure (doses t.h ${ }^{1}$ ) } \\
\hline $\mathrm{V}_{17}(0)$ & $15.00 \mathrm{a}$ & $30.67 \mathrm{abc}$ & $53.00 \mathrm{a}$ & $50.00 \mathrm{abc}$ \\
\hline $\mathrm{V}_{18}(5)$ & $19.33 \mathrm{ab}$ & $32.67 \mathrm{abc}$ & $59.67 \mathrm{ab}$ & $54.00 \mathrm{abc}$ \\
\hline $\mathrm{V}_{19}(10)$ & $22.33 \mathrm{ab}$ & $37.67 \mathrm{bc}$ & $58.00 \mathrm{ab}$ & $63.33 \mathrm{c}$ \\
\hline $\mathrm{V}_{20}(15)$ & $23.00 \mathrm{ab}$ & $38.67 \mathrm{bc}$ & $63.67 \mathrm{ab}$ & $68.00 \mathrm{c}$ \\
\hline LSD & 12.575 & $\mathbf{1 1 . 5 3 7}$ & 22.830 & 32.195 \\
\hline
\end{tabular}

Notes: The same letters in the same column were not significant difference at $5 \%$ LSD test.

The increase in plant height, the number of leaves, and the number of tillers of shallots are related to the humus content excreted by earthworms that contain humic acid. Humic acid functions in increasing plant growth hormones and symbiosis with microorganisms that are beneficial in increasing plant height and leaf number [43]. Besides containing humic acid, the humus material also functions to increase soil aggregation, thereby ensuring better aeration. Shallots have relatively short roots and do not spread, so to get optimal rooting, red onions need a rooting medium with a balanced aeration capacity and media water storage [44].

A suitable root medium should generally have an optimal volume of gas-filled pore space and an adequate level of oxygen diffusion for respiration needs, will have a positive impact on the translocation of carbohydrates and other 
nutrients to the root area. Furthermore, increasing soil aggregation will increase the absorption of nutrients by plants. This is in accordance with the research [42] that giving vermicompost to shallots can increase plant vegetative growth because vermicompost has a high nitrate content so that more nitrogen is available for plants.

\subsection{Effect vermicompost formulation based on soybean husk and cow manure on Shallots Yield}

According to Table 4, yield variables including number of bulb per plant, weight of bulb per plant, weight of each bulb and yield showed a significant effect on $\mathrm{V}_{4}$ treatment $(100 \%$ soybean husk) at a dose of 15 t.ha $^{1}$ and treatment relatively less occurred in the treatment without application of vermicompost on all formulations. In more detail, the average of all outcome variables was presented in the following Tables 2 and 3 Number of Bulbs per Plant (NBPP), Weight of Bulbs per Plant (WBPP) (g), Weight of Each Bulb (WEB) (g), and Yields (Y) $\left(\mathrm{t} . \mathrm{ha}^{-1}\right)$ Shallots In Vermicompost Formulation Test Made from soybean husk and cow manure.

The application of vermicompost with different raw material formulations and dosages showed different effects on crop yields. Vermicompost made from $100 \%$ raw material waste from soybean husk at a dose of $15 \mathrm{t} \mathrm{ha}^{1}$ gave the highest yields on the number of bulbs per plant, weight of bulbs per plant, weight of each bulb, and yields. The number of bulbs per plant reached 22.22 , this number was $11.1 \%$ higher than the control. The weight of bulbs per plant in the formulation of $100 \%$ soybean husk at a dose of $15 \mathrm{t}$. ha ${ }^{1}$ was $56.11 \mathrm{~g}$, and when compared to the control treatment the formulation was $14.76 \%$ higher. The highest weight of each bulb was $10.16 \mathrm{~g}$, which was $26.14 \%$ higher than the control. Furthermore, the yield of 13.09 t.ha ${ }^{1}$ was the highest and when compared to the control, the yield was $14.78 \%$ higher.
Table 3. The effect of vermicompost formulation on number of tillers variable at several age measurements (days after planting/dap)

\begin{tabular}{|c|c|c|c|c|}
\hline \multirow{2}{*}{ Treatment } & \multicolumn{4}{|c|}{ Number of tillers / age (dap) } \\
\hline & 20 & 30 & 40 & 50 \\
\hline \multicolumn{5}{|c|}{$100 \%$ soybean husk (doses t.h ${ }^{1}$ ) } \\
\hline $\mathrm{V}_{1}(0)$ & $4.67 \mathrm{ab}$ & $6.33 \mathrm{ab}$ & $12.67 \mathrm{ab}$ & $12.67 \mathrm{ab}$ \\
\hline $\mathrm{V}_{2}(5)$ & $6.00 \mathrm{ab}$ & $8.33 \mathrm{ab}$ & $14.00 \mathrm{ab}$ & $13.00 \mathrm{ab}$ \\
\hline $\mathrm{V}_{3}(10)$ & $6.00 \mathrm{ab}$ & $9.00 \mathrm{ab}$ & $15.33 \mathrm{~b}$ & $14.33 \mathrm{ab}$ \\
\hline $\mathrm{V}_{4}(15)$ & $6.33 \mathrm{~b}$ & $11.33 \mathrm{~b}$ & $15.67 \mathrm{c}$ & $15.67 \mathrm{~b}$ \\
\hline \multicolumn{5}{|c|}{$100 \%$ cow manure (doses t.h $\left.{ }^{1}\right)$} \\
\hline $\mathrm{V}_{5}(0)$ & $4.00 \mathrm{a}$ & $6.00 \mathrm{a}$ & $10.67 \mathrm{a}$ & $9.33 \mathrm{a}$ \\
\hline $\mathrm{V}_{6}(5)$ & $5.00 \mathrm{ab}$ & $6.00 \mathrm{a}$ & $12.33 \mathrm{ab}$ & $10.67 \mathrm{ab}$ \\
\hline $\mathrm{V}_{7}(10)$ & $5.33 \mathrm{ab}$ & $7.33 \mathrm{ab}$ & $12.00 \mathrm{ab}$ & $11.33 \mathrm{ab}$ \\
\hline $\mathrm{V}_{8}(15)$ & $5.00 \mathrm{ab}$ & $7.33 \mathrm{ab}$ & $13.00 \mathrm{ab}$ & $12.33 \mathrm{ab}$ \\
\hline \multicolumn{5}{|c|}{ 50\% soybean husk: $50 \%$ cow manure (doses t.h $\left.{ }^{1}\right)$} \\
\hline $\mathrm{V}_{9}(0)$ & $4.00 \mathrm{a}$ & $6.00 \mathrm{a}$ & $12.33 \mathrm{ab}$ & $10.33 \mathrm{ab}$ \\
\hline $\mathrm{V}_{10}(5)$ & $5.00 \mathrm{ab}$ & $7.33 \mathrm{ab}$ & $13.00 \mathrm{ab}$ & $11.67 \mathrm{ab}$ \\
\hline $\mathrm{V}_{11}(10)$ & $5.33 \mathrm{ab}$ & $8.00 \mathrm{ab}$ & $13.33 \mathrm{ab}$ & $13.00 \mathrm{ab}$ \\
\hline $\mathrm{V}_{12}(15)$ & $5.67 \mathrm{ab}$ & $8.67 \mathrm{ab}$ & $15.00 \mathrm{ab}$ & $14.00 \mathrm{ab}$ \\
\hline \multicolumn{5}{|c|}{$75 \%$ soybean husk: $25 \%$ cow manure (doses t.h ${ }^{1}$ ) } \\
\hline $\mathrm{V}_{13}(0)$ & $4.33 \mathrm{ab}$ & $6.00 \mathrm{a}$ & $11.33 \mathrm{ab}$ & $10.33 \mathrm{ab}$ \\
\hline$V_{14}(5)$ & $4.67 \mathrm{ab}$ & $6.67 \mathrm{ab}$ & $13.67 \mathrm{ab}$ & $13.67 \mathrm{ab}$ \\
\hline $\mathrm{V}_{15}(10)$ & $5.00 \mathrm{ab}$ & $7.00 \mathrm{ab}$ & $14.00 \mathrm{ab}$ & $14.00 \mathrm{ab}$ \\
\hline $\mathrm{V}_{16}(15)$ & $6.33 \mathrm{~b}$ & $8.33 \mathrm{ab}$ & $14.67 \mathrm{ab}$ & $15.33 \mathrm{ab}$ \\
\hline \multicolumn{5}{|c|}{$25 \%$ soybean husk: $75 \%$ cow manure (doses t.h $\left.{ }^{1}\right)$} \\
\hline $\mathrm{V}_{17}(0)$ & $4.00 \mathrm{a}$ & $6.00 \mathrm{a}$ & $11.00 \mathrm{ab}$ & $11.33 \mathrm{ab}$ \\
\hline$V_{18}(5)$ & $4.67 \mathrm{ab}$ & $7.67 \mathrm{ab}$ & $12.00 \mathrm{ab}$ & $12.00 \mathrm{ab}$ \\
\hline $\mathrm{V}_{19}(10)$ & $5.67 \mathrm{ab}$ & $8.33 \mathrm{ab}$ & $13.00 \mathrm{ab}$ & $14.33 \mathrm{ab}$ \\
\hline $\mathrm{V}_{20}(15)$ & $6.33 \mathrm{~b}$ & $10.67 \mathrm{ab}$ & $14.00 \mathrm{ab}$ & $15.33 \mathrm{ab}$ \\
\hline LSD & 2.121 & 5.082 & 4.494 & 6.331 \\
\hline
\end{tabular}

Notes: The same letters in the same column were not significant difference at $5 \%$ LSD test.

Table 4. The effect of vermicompost formulation on yield variable of shallot at several age measurements

\begin{tabular}{|c|c|c|c|c|c|}
\hline $\mathbf{T}$ & NBPP & WBPP $(g)$ & WEB (g) & BD $(\mathbf{c m})$ & $\mathbf{Y}\left(\mathbf{t} \cdot \mathbf{h}^{\mathbf{1}}\right)$ \\
\hline \multicolumn{6}{|c|}{$100 \%$ soybean husk (doses t.h $\left.{ }^{1}\right)$} \\
\hline $\mathrm{V}_{1}(0)$ & $9.33 \mathrm{a}$ & $42.78 \mathrm{abc}$ & $5.95 \mathrm{a}$ & $22.40 \mathrm{ab}$ & $9.72 \mathrm{ab}$ \\
\hline $\mathrm{V}_{2}(5)$ & $10.22 \mathrm{ab}$ & $51.67 \mathrm{bc}$ & $7.04 \mathrm{ab}$ & $23.59 \mathrm{ab}$ & $11.93 \mathrm{ab}$ \\
\hline $\mathrm{V}_{3}(10)$ & $11.17 \mathrm{ab}$ & $52.72 \mathrm{bc}$ & $7.18 \mathrm{ab}$ & $24.12 \mathrm{ab}$ & $12.31 \mathrm{ab}$ \\
\hline $\mathrm{V}_{4}(15)$ & $10.72 \mathrm{ab}$ & $56.11 \mathrm{c}$ & $10.16 \mathrm{~b}$ & $27.48 \mathrm{~b}$ & $13.09 \mathrm{~b}$ \\
\hline \multicolumn{6}{|c|}{$100 \%$ cow manure $\left(\right.$ doses $\left.t . h^{1}\right)$} \\
\hline $\mathrm{V}_{5}(0)$ & $9.78 \mathrm{ab}$ & 34,44 a & $5.88 \mathrm{a}$ & $13.34 \mathrm{a}$ & $8,04 \mathrm{a}$ \\
\hline $\mathrm{V}_{6}(5)$ & $10.51 \mathrm{ab}$ & $44.44 \mathrm{abc}$ & $6.79 a b$ & $21.61 \mathrm{ab}$ & $10.37 \mathrm{ab}$ \\
\hline $\mathrm{V}_{7}(10)$ & $11.28 \mathrm{ab}$ & $45.00 \mathrm{abc}$ & $6.78 \mathrm{ab}$ & $20.67 \mathrm{ab}$ & $10.50 \mathrm{ab}$ \\
\hline $\mathrm{V}_{8}(15)$ & $12.22 \mathrm{~b}$ & $47.22 \mathrm{abc}$ & $6.46 \mathrm{ab}$ & $23.59 \mathrm{ab}$ & $11.06 \mathrm{ab}$ \\
\hline \multicolumn{6}{|c|}{ 50\% soybean husk: $50 \%$ cow manure (doses t.h ${ }^{1}$ ) } \\
\hline $\mathrm{V}_{9}(0)$ & $9.56 \mathrm{ab}$ & $37.22 \mathrm{abc}$ & $7.18 \mathrm{ab}$ & $19.39 \mathrm{ab}$ & $8.68 \mathrm{ab}$ \\
\hline $\mathrm{V}_{10}(5)$ & $11.11 \mathrm{ab}$ & $48.33 \mathrm{abc}$ & $6.39 \mathrm{ab}$ & $19.80 \mathrm{ab}$ & $10.37 \mathrm{ab}$ \\
\hline $\mathrm{V}_{11}(10)$ & $10.22 \mathrm{ab}$ & $47.22 \mathrm{abc}$ & $8.18 \mathrm{ab}$ & $21.91 \mathrm{ab}$ & $11.93 \mathrm{ab}$ \\
\hline $\mathrm{V}_{12}(15)$ & $10.00 \mathrm{ab}$ & $47.22 \mathrm{abc}$ & $7.39 \mathrm{ab}$ & $23.56 \mathrm{ab}$ & $12.31 \mathrm{ab}$ \\
\hline \multicolumn{6}{|c|}{$75 \%$ soybean husk: $25 \%$ cow manure (doses t.h $\left.{ }^{1}\right)$} \\
\hline $\mathrm{V}_{13}(0)$ & $9.33 \mathrm{a}$ & $42.78 \mathrm{abc}$ & $6.02 \mathrm{a}$ & $22.61 \mathrm{ab}$ & $9.98 \mathrm{ab}$ \\
\hline $\mathrm{V}_{14}(5)$ & $10.89 \mathrm{ab}$ & $43.33 \mathrm{abc}$ & $8.56 \mathrm{ab}$ & $22.17 \mathrm{ab}$ & $10.11 \mathrm{ab}$ \\
\hline $\mathrm{V}_{15}(10)$ & $10.56 \mathrm{ab}$ & $46.11 \mathrm{abc}$ & $7.50 \mathrm{ab}$ & $22.70 \mathrm{ab}$ & $10.76 \mathrm{ab}$ \\
\hline $\mathrm{V}_{16}(15)$ & $10.17 \mathrm{ab}$ & $46.67 \mathrm{abc}$ & $7.34 \mathrm{ab}$ & $26.07 \mathrm{~b}$ & $10.89 \mathrm{ab}$ \\
\hline \multicolumn{6}{|c|}{$25 \%$ soybean husk: $75 \%$ cow manure (doses t.h ${ }^{1}$ ) } \\
\hline $\mathrm{V}_{17}(0)$ & $9.78 \mathrm{ab}$ & $41.67 \mathrm{abc}$ & $5.59 \mathrm{a}$ & $19.59 \mathrm{ab}$ & $9.98 \mathrm{ab}$ \\
\hline $\mathrm{V}_{18}(5)$ & $10.89 \mathrm{ab}$ & $43.06 \mathrm{abc}$ & $8.95 \mathrm{ab}$ & $22.78 \mathrm{ab}$ & $10.37 \mathrm{ab}$ \\
\hline $\mathrm{V}_{19}(10)$ & $10.44 \mathrm{ab}$ & $44.44 \mathrm{abc}$ & $6.37 \mathrm{ab}$ & $23.91 \mathrm{ab}$ & $11.02 \mathrm{ab}$ \\
\hline $\mathrm{V}_{20}(15)$ & $10.15 \mathrm{ab}$ & $47.22 \mathrm{abc}$ & $6.44 \mathrm{ab}$ & $25.38 \mathrm{~b}$ & $11.02 \mathrm{ab}$ \\
\hline LSD & 2.758 & 16.723 & 3.847 & 10.848 & 4.540 \\
\hline
\end{tabular}


The application of vermicompost with different raw material formulations and dosages showed different effects on crop yields. Vermicompost made from $100 \%$ raw material waste from soybean husk at a dose of $15 \mathrm{t}^{\mathrm{h} \mathrm{a}^{1}}$ gave the highest yields on the number of bulbs per plant, bulbs weight per plant, weight per bulbs, and yield per hectare. In addition to containing macronutrients and micronutrients, vermicompost also contains enzymes such as amylase, lipase, and cellulose as well as beneficial bacteria such as mycorrhizae [12, 42]. This enzyme continues to break down organic matter in the soil to release various nutrients and into forms available to plants, thus affecting the yield of shallots.

The availability of sufficient nutrients in vermicompost made from $100 \%$ raw material soybean husk at a dose of 15 t.ha ${ }^{1}$, led to increased leaf growth and photosynthesis. Photosynthesis is highly correlated with the number of leaves produced, where the more the number of leaves, the more photosynthesis is produced because photosynthesis is more effective. The resulting photosynthate is then translocated to the generative organs (bulbs) [45] in the transitional phase between the vegetative phase and the generative phase. The development of bulbs is influenced by the metabolism of fructan precursors which accumulate as reserve substances [46] wherein vermicompost, these reserves are represented by polysaccharides which accumulate from the beginning of bulb formation and there is a two-fold increase so that there is also an increase in size, quality and yields. These results are similar to research conducted by Abolmaaty [47] that the application of vermicompost increases the yield of onion bulbs.

\section{CONCLUSION}

The potential of soybean husk as a raw material for making organic fertilizers has been proven to increase the growth and yield of shallots. This is evident from the tests that have been carried out, where in the treatment of $100 \%$ soybean husk formulation at a dose of 15 t.ha $^{1}$ was able to provide an increase in yields of $14.78 \%$ higher than the treatment without vermicompost.

\section{ACKNOWLEDGMENT}

The author would like to thank the University of Muhammadiyah Malang for supporting and funding this research.

\section{REFERENCES}

[1] Ounjaijean, S., Chachiyo, S., Kulprachakarn, K., Boonyapranai, K., Srichairatanakool, S., Rerkasem, K. (2019). Antioxidant and anti-inflammatory protective properties of Thai shallot (allium ascalonicum cv. Chiangmai) juice on human vascular endothelial cell lines (EA.hy926). Walailak J. Sci. Technol., 16(3): 175184. https://doi.org/10.48048/wjst.2019.6222

[2] Ning, C.C., Gao P.D., Wang, B.Q., Lin, W.P., Jiang, N.H., Cai, K.Z. (2017). Impacts of chemical fertilizer reduction and organic amendments supplementation on soil nutrient, enzyme activity and heavy metal content. J. Integr. $\quad$ Agric., 16(8): 1819-1831. https://doi.org/10.1016/S2095-3119(16)61476-4
[3] Ansar, M., Bahrudin, Darman, S., Paiman, (2020). Application of bokashi fertilizer and duration of water supply to increase growth, yields, and quality of shallot in dryland. International Journal of Design \& Nature and Ecodynamics, $15(5)$ : 711-719. https://doi.org/10.18280/ijdne.150513

[4] Ye, L., Zhao, X., Bao, E., Li, J., Zou, Z., Cao, K. (2020). Bio-organic fertilizer with reduced rates of chemical fertilization improves soil fertility and enhances tomato yield and quality. Sci. Rep., 10(1): 1-11. https://doi.org/10.1038/s41598-019-56954-2

[5] Wang, J., Song, Y., Ma, T., Raza, W., Li, J., Howland, J. G., Huang, Q., Shen, Q. (2017). Impacts of inorganic and organic fertilization treatments on bacterial and fungal communities in a paddy soil. Appl. Soil Ecol., 112: 4250. https://doi.org/10.1016/j.apsoil.2017.01.005

[6] Gu, S., Hu, Q., Cheng, Y., Bai, L., Liu, Z., Xiao, W., Gong, Z., Wu, Y., Feng, K., Deng, Y., Tan, L. (2019). Application of organic fertilizer improves microbial community diversity and alters microbial network structure in tea (Camellia sinensis) plantation soils. Soil and Tillage Research, 195: 104356. https://doi.org/10.1016/j.still.2019.104356

[7] Chen, W., Teng, Y., Li, Z., Liu, W., Ren, W., Luo, Y., Christie, P. (2018). Mechanisms by which organic fertilizer and effective microbes mitigate peanut continuous cropping yield constraints in a red soil of south China. Applied Soil Ecology, 128: 23-34. https://doi.org/10.1016/j.apsoil.2018.03.018

[8] Laurent, C., Bravin, M.N., Crouzet, O., Pelosi, C., Tillard, E., Lecomte, P., Lamy, I. (2020). Increased soil pH and dissolved organic matter after a decade of organic fertilizer application mitigates copper and zinc availability despite contamination. Sci. Total Environ., 709:

135927. https://doi.org/10.1016/j.scitotenv.2019.135927

[9] Bhat, S.A., Singh, J., Vig, A.P. (2017). Instrumental characterization of organic wastes for evaluation of vermicompost maturity. J. Anal. Sci. Technol., 8(2). https://doi.org/10.1186/s40543-017-0112-2

[10] Blouin, M., Barrere, J., Meyer, N., Lartigue, S., Barot, S., Mathieu, J. (2019). Vermicompost significantly affects plant growth. A meta-analysis. Agron. Sustain. Dev., 39(34): 1-15. https://doi.org/10.1007/s13593-019-0579$\mathrm{X}$

[11] Gong, X., Li, S., Carson, M.A., Chang S.X., Wu, Q., Wang, L., An, Z., Sun, X. (2019). Spent mushroom substrate and cattle manure amendments enhance the transformation of garden waste into vermicomposts using the earthworm Eisenia fetida. J. Environ. Manage., 248: 109263. https://doi.org/10.1016/j.jenvman.2019.109263

[12] Arumugam, K., Renganathan, S., Babalola, O.O., Muthunarayanan, V. (2018). Investigation on paper cup waste degradation by bacterial consortium and Eudrillus eugeinea through vermicomposting. Waste Manag., 74: 185-193. https://doi.org/10.1016/j.wasman.2017.11.009

[13] Gong, X., Cai, L., Li, S., Chang, S. X., Sun, X., An, Z. (2018). Bamboo biochar amendment improves the growth and reproduction of Eisenia fetida and the quality of green waste vermicompost. Ecotoxicol. Environ. Saf., 156: 197-204. https://doi.org/10.1016/j.ecoenv.2018.03.023

[14] Srivastava, V., Goel, G., Thakur, V.K., Singh, R.P., 
Ferreira de Araujo, A.S., Singh, P. (2020). Analysis and advanced characterization of municipal solid waste vermicompost maturity for a green environment. J. Environ. Manage., 109914 https://doi.org/10.1016/j.jenvman.2019.109914

[15] Rupani, P.F., Embrandiri, A., Ibrahim, M.H., Shahadat, M., Hansen, S.B., Mansor, N.N.A. (2017). Bioremediation of palm industry wastes using vermicomposting technology: Its environmental application as green fertilizer. 3 Biotech, 7: 155. https://doi.org/10.1007/s13205-017-0770-1

[16] Sharma K., Garg, V.K., (2017). Management of food and vegetable processing waste spiked with buffalo waste using earthworms (Eisenia fetida). Environ. Sci. Pollut. Res., 24: 7829-7836. https://doi.org/10.1007/s11356017-8438-2

[17] Paradelo, R., Vecino, X., Moldes, A.B., Barral, M.T. (2019). Potential use of composts and vermicomposts as low-cost adsorbents for dye removal: An overlooked application. Environ. Sci. Pollut. Res., 26(21): 2108521097. https://doi.org/10.1007/s11356-019-05462-X

[18] Biruntha, M., Karmegam, N., Aechana, J., Selvi, B.K., Paul, J.A.J., Balamuralikrishnan, B., Chang, S.W., Ravidran, B. (2020). Vermiconversion of biowastes with low-to-high $\mathrm{C} / \mathrm{N}$ ratio into value added vermicompost. Bioresour. $\quad$ Technol., 122398. https://doi.org/10.1016/j.biortech.2019.122398

[19] Rini, J., Deepthi, M.P., Saminathan, K., Narendhirakannan, R.T., Karmegam, N., Kathireswari, P. (2020). Nutrient recovery and vermicompost production from livestock solid wastes with epigeic earthworms," Bioresour. $\quad$ Technol., $\quad 313$ : 123690. https://doi.org/10.1016/j.biortech.2020.123690

[20] Ravindran, B., Contreras-Ramos, S.M., Sekaran, G. (2015). Changes in earthworm gut associated enzymes and microbial diversity on the treatment of fermented tannery waste using epigeic earthworm Eudrilus eugeniae. Ecol. Eng., 74: 394-401. https://doi.org/10.1016/j.ecoleng.2014.10.014

[21] Song, X., Liu, M., Wu., D., Griffiths, B. S., Jiao, J., Li, H., Hu, F. (2015). Interaction matters: Synergy between vermicompost and PGPR agents improves soil quality, crop quality and crop yield in the field. Appl. Soil Ecol., 89: 25-34. https://doi.org/10.1016/j.apsoil.2015.01.005

[22] Olivares, F. L., Aguiar, N.O., Rosa, R.C.C., Canellas, L.P. (2015). Substrate biofortification in combination with foliar sprays of plant growth promoting bacteria and humic substances boosts production of organic tomatoes. Sci. Hortic. (Amsterdam)., 183: 100-108. https://doi.org/10.1016/j.scienta.2014.11.012

[23] Alikhani, H.A., Hemati, A., Rashtbari, M., Tiegs, S.D., Etesami, H. (2017). Enriching vermicompost using psolubilizing and n-fixing bacteria under different temperature conditions. Commun. Soil Sci. Plant Anal., 48(2):

139-147. https://doi.org/10.1080/00103624.2016.1206913

[24] Mu, J., Li, X., Jiao, J., Ji, G., Wu, J., Hu, F., Li, H. (2017). Biocontrol potential of vermicompost through antifungal volatiles produced by indigenous bacteria. Biol. Control, 112:

49-54. https://doi.org/10.1016/j.biocontrol.2017.05.013

[25] Balachandar, R., Karmegam, N., Saravanan, M., Subbaiya, R., Gurumoorthy, P. (2018). Synthesis of bioactive compounds from vermicast isolated actinomycetes species and its antimicrobial activity against human pathogenic bacteria. Microb. Pathog., 121: 155-165. https://doi.org/10.1016/j.micpath.2018.05.027

[26] Shi, Z., Tang, Z., Wang, C. (2019). Effect of phenanthrene on the physicochemical properties of earthworm casts in soil. Ecotoxicol. Environ. Saf., 168: 348-355. https://doi.org/10.1016/j.ecoenv.2018.10.032

[27] Gómez-Brandon, M., Vela, M., Martínez-Toledo, M.V., Insam, H., Domínguez, J., (2014). Effects of compost and vermicompost teas as organic fertilizers. In: Sinha, S., Pant, K.K., Bajpai, S. (Eds), Advances in Fertilizer Technology: Synthesis (Vol. 1). Studium Press, LLC, USA, pp. 300-318.

[28] Asgele, K., Woldetsadik, K., Gedamu, Y., Arvind, C. (2018). Effect of inorganic NP fertilizers and vermicompost on seed yield and seed quality of onion (Allium cepa L.) at Maitsebri, Northern Ethiopia. Journal of Horticulture and Forestry, 10(6): 89-96. https://doi.org/10.5897/JHF2018.0533

[29] Benazzouk, S., Djazouli, Z.E., Lutts S. (2018). Assessment of the preventive effect of vermicompost on salinity resistance in tomato (Solanum lycopersicum $\mathrm{cv}$. Ailsa Craig). Acta Physiol. Plant., 40: 121. https://doi.org/10.1007/s11738-018-2696-6

[30] Truong, H.D., Wang, C.H., Kien, T. (2018). Effect of vermicompost in media on growth, yield and fruit quality of cherry tomato (Lycopersicon esculentun Mill.) under net house conditions. Compost Sci. Util., 26(1): 52-58. https://doi.org/10.1080/1065657X.2017.1344594

[31] Zuo, Y.N., Zhang, J.X., Zhao, R., Dai, H.G., Zhang, Z.H. (2018). Application of vermicompost improves strawberry growth and quality through increased photosynthesis rate, free radical scavenging and soil enzymatic activity. Sci. Hortic. (Amsterdam)., 233: 132140. https://doi.org/10.1016/j.scienta.2018.01.023

[32] Rekha, G.S., Kaleena, P.K., Elumalai, D., Srikumaran, M.P., Maheswari, V.N. (2018). Effects of vermicompost and plant growth enhancers on the exo-morphological features of Capsicum annum (Linn.) Hepper. Int. J. Recycl. Org. Waste Agric., 7: 83-88. https://doi.org/10.1007/s40093-017-0191-5

[33] Lim, P.N., Wu, T.Y., Shyang Sim, E.Y., Lim, S.L. (2011). The potential reuse of soybean husk as feedstock of Eudrilus eugeniae in vermicomposting. J. Sci. Food Agric., 91(14): 2637-2642. https://doi.org/10.1002/jsfa.4504

[34] Srivastava, V., Gupta, S.K., Singh, P., Sharma, B., Singh, R.P. (2018). Biochemical, physiological, and yield responses of lady's finger (Abelmoschus esculentus L.) grown on varying ratios of municipal solid waste vermicompost. Int. J. Recycl. Org. Waste Agric., 7(3): 241-250. https://doi.org/10.1007/s40093-018-0210-1

[35] Yuvaraj, A., Karmegam, N., Thangaraj, R. (2018). Vermistabilization of paper mill sludge by an epigeic earthworm Perionyx excavatus: Mitigation strategies for sustainable environmental management. Ecol. Eng., 120: 187-197. https://doi.org/10.1016/j.ecoleng.2018.06.008

[36] Williams, L.J., Abdi, H. (2010). Tukey's Honestly Significant Difference test (HSD). In Neil Salkind (Ed.), Encyclopedia of Research Design, Thousand Oaks, CA.

[37] Fikru T.K., Fikreyohannes, G. (2019). Effect of vermicompost on growth, quality and economic return of garlic (Allium sativum L.) at Haramaya District, Eastern Ethiopia. African J. Agric. Res., 14(35): 2159-2167. 
https://doi.org/10.5897/ajar2017.12760

[38] Adugna, G. (2016). A review on impact of compost on soil properties, water use and crop productivity. Agric. $\begin{array}{llll}\text { Sci. } & \text { Res. } & \text { J., } & \text { 4(3): }\end{array}$ https://doi.org/10.14662/ARJASR2016.010

[39] Singh, A., Bhadauria, T., Karmegam, N., Chang, S.W., Sudhakar, S., Ravindran, B., Singh, G.S., Awasthi, M.K., Arunachalam, K.D., Biruntha M. (2020). Earthworms and vermicompost: An eco-friendly approach for repaying nature's debt. Environ. Geochem. Health, 42(6): 1617-1642. https://doi.org/10.1007/s10653-019-00510-4

[40] Lazcano, C., Gómez-Brandón, M., Domínguez, J. (2008). Comparison of the effectiveness of composting and vermicomposting for the biological stabilization of cattle manure. Chemosphere, 72(7): 1013-1019. https://doi.org/10.1016/j.chemosphere.2008.04.016

[41] Engels, C., Kirkby, E., White, P. (2011). Mineral nutrition, yield and source-sink relationships. In book: Marschner's Mineral Nutrition of Higher Plants, pp. 85133. https://doi.org/10.1016/B978-0-12-3849052.00005-4

[42] Acharya, S., Kumar, H. (2018). Effect of some organic manure on growth and yield of garlic in greenhouse condition at cold desert high altitude Ladakh region. Def. $\begin{array}{llll}\text { Life } & \text { Sci. } & \text { J., } & \text { 3(2): }\end{array}$ https://doi.org/10.14429/dlsj.3.12569

[43] Elsawy, A.M., Essa, E.M., Abd, E., Rheem, M.K. (2019). Effect of vermicompost and sulfur on growth, yield and nutritional status of tomato plants grown on Calcareous Soil.

[44] Ofori, D.A., Newton, A.C., Leakey, R.R.B., Grace, J. (1996). Vegetative propagation of Milicia excelsa by leafy stem cuttings: Effects of auxin concentration, leaf area and rooting medium. For. Ecol. Manage., 84(1-3): 39-48. https://doi.org/10.1016/0378-1127(96)03737-1

[45] Yohannes, K.W., Belew, D., Debela, A. (2014). Effect of farmyard manure and nitrogen fertilizer rates on growth, yield and yield components of onion (Allium Cepa L.) at Jimma, southwest Ethiopia. Asian Journal of Plant Sciences, 12(6-8): 228-234. https://doi.org/10.3923/ajps.2013.228.234

[46] Argüello, J.A., Ledesma, A., Núñez, S.B., Rodríguez, C.H., Díaz Goldfarb, M.D.C. (2006). Vermicompost effects on bulbing dynamics, nonstructural carbohydrate content, yield, and quality of 'Rosado Paraguayo' garlic bulbs. HortScience, 41(3): 589-592. https://doi.org/10.21273/hortsci.41.3.589

[47] Abolmaaty, S.M. (2016). Effect of vermicompost treatments and EM1 on onion white rot disease. Adv. Res., 3(8): 658-669. 